\title{
In Memoriam Franz Koelsch
}

Am 30. November 1970 ist der Nestor der Arbeitsmedizin, ihr Pionier und Mitbegründer im 95. Lebensjahr in Erlangen verstorben. Er genoß hohes internationales Ansehen. Mit dem Archiv war er seit Begründung desselben als ,,Archiv für Gewerbepathologie und Gewerbehygiene" durch seine Mitwirkung verbunden.

Person und Werk des um die Arbeitsmedizin so hochverdienten Mannes sind anläßlich seines 90. Geburtstages hier bereits gewürdigt worden [E. Lederer: „Franz Koelsch 90 Jahre", Int. Arch. Gewerbepath. Gewerbehyg. 22, 95-113 (1966)].

Sein Geist und Vorbild werden in der Geschichte der Arbeitsmedizin weiterleben!

Herausgeber und Verlag 